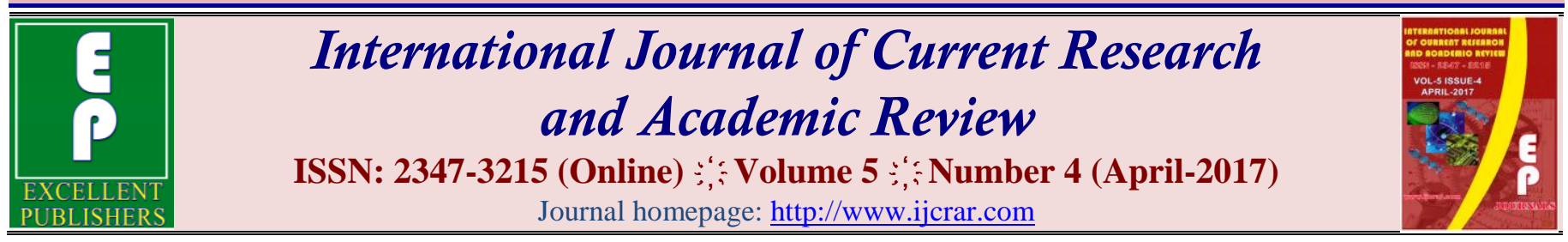

doi: $\underline{\text { https://doi.org/10.20546/ijcrar.2017.504.011 }}$

\title{
In vitro Anticancer Activity of Marine Fungus Penicillium cyaneum
}

\author{
A. Xavier Fernandes ${ }^{1 *}$, S. Mohamed Salique ${ }^{1}$ and K. Umamagheswari ${ }^{2}$ \\ ${ }^{1}$ Department of Botany, Jamal Mohamed College (Aut.), Trichy - 620 020, Tamil Nadu, India \\ ${ }^{2}$ Department of Chemistry, Manonmaniam Sundaranar University, Tirunelveli, 627 012, India
}

*Corresponding author:

\begin{abstract}
Cancer is one of the most life-threatening diseases worldwide. Over the last few years, several metabolites produced by marine fungi have displayed potent anticancer effects. In the present study the anticancer activity of marine fungus Penicillium cyaneum against HepG 2 cells (human liver carcinoma cells) was assessed by in vitro cytotoxicity assay. The results revealed that $P$. cyaneum ethyl acetate extract showed potent cytotoxic effects in HepG 2 cells, with cell viability $(29.5 \%)$ observed at $1000 \mu \mathrm{g} / \mathrm{mL}$. The $\mathrm{IC}_{50}$ of ethyl acetate extract of $P$. cyaneum was $242.24 \mu \mathrm{g} / \mathrm{mL}$.
\end{abstract}

\section{Article Info}

Accepted: 08 April 2017

Available Online: 20 April 2017

\section{Keywords}

Cancer, marine fungus,

HepG 2, cytotoxicity.

\section{Introduction}

Cancer is a generic term for a large group of diseases characterized by the growth of abnormal cells beyond their usual boundaries that can then invade adjoining parts of the body and/or spread to other organs. Cancer can affect almost any part of the body and has many anatomic and molecular subtypes that each requiring specific management strategies. Cancer is the second leading cause of death globally and accounted for 8.8 million deaths in 2015. Lung, prostate, colorectal, stomach and liver cancer are the most common types of cancer in men, while breast, colorectal, lung, cervix and stomach cancer are the most common among women (WHO, 2017). In India, around 2.5 million of people living with the disease, 556400 national cancer deaths occurred in 2010. 395400 (71\%) cancer deaths occurred in people aged 30-69 years (200 100 men and 195300 women). Every year, 7 lakhs new cancer patients registered. Cancers of oral cavity and lungs in males and cervix and breast in females account for over $50 \%$ of all cancer deaths in India (Nandakumar, 2009; Dikshit et al.,
2012). The biggest challenges in the field of cancer biology are to discover an anticancer drug which has the ability to kill the cancer cells without any side effects to the surrounding cells. The recent and systematic chemical characterization of fungi from the marine environment has provided a total number that currently exceeds 1000 new natural products (Rateb and Ebel, 2011; Gomes et al., 2015). The marine fungus is having the ability to produce chemically unique bioactive molecules, which is supported by the identification of new anticancer metabolites through the application of classical screening and isolation techniques. Therefore, in the present study we designed to study the anticancer activity of marine fungus against HepG 2 cells (human liver carcinoma cells).

\section{Materials and Methods}

\section{Isolation and identification of mangrove fungus}

Dilution plating technique described by Waksman (1922) was used to isolate the mycoflora from soils. The fungus 
$P$. cyaneum was isolated from mangrove soil of Karankadu, Ramanathapuram Dt, Tami Nadu, India. The identification was done by using standard manuals such as Manual of Penicillia (Raper and Thom, 1949) and Manual of Soil fungi (Gillman, 1957).

\section{Preparation ethyl acetate extract from $P$. cyaneum}

The crude ethyl acetate extract from $P$. cyaneum was prepared following the methodology described by Joel and Bhimba (2012).

\section{Fungal broth culture}

In order to obtain secondary metabolites the pure culture of $P$. cyaneum was grown in potato dextrose broth culture medium at $28^{\circ} \mathrm{C}$ for 3 days. After that a preinoculum was prepared by introducing small fragments $(1 \mathrm{~cm}$ square) of the growth culture into $250 \mathrm{ml}$ Erlenmeyer flasks containing potato dextrose broth and cultivated on a rotary shaker at $200 \mathrm{rpm}, 28^{\circ} \mathrm{C}$ for 5 days. Then the mycelium and the filtrate were separately subjected to solvent extraction.

\section{Extraction of mycelia}

The fresh mycelium of $P$. cyaneum was washed three times with water (distilled water: sea water 1:1) to remove adherent filtrate, and then plotted between folds of whatman filter paper no 1 . The plotted mycelium was crushed using mortar and pestle with ethyl acetate and subjected to sonication (Labsonic, Sartorious, Germany) for 3 -4 hours to obtain intracellular metabolites. Centrifuged at $2000-2500 \mathrm{rpm}$ for $5 \mathrm{mins}$ and the supernatant was used for further studies.

\section{Extraction of the filtrate}

The filtrate of $P$. cyaneum was extracted several times with ethyl acetate $(\mathrm{v} / \mathrm{v})$ in a separating funnel. The extracts from both mycelia and filtrate were evaporated under vaccum at $50^{\circ} \mathrm{C}$ till dryness. The obtained solid material was dissolved in ethyl acetate to form the crude extract and tested for cytotoxicity assay.

\section{Cell culture of cancer cells and Cytotoxicity assay}

\section{Cell culture}

HepG 2 cells obtained from NCCS (National Centre For Cell Science, Pune) were cultured in Rose well Park Memorial Institute medium (RPMI), supplemented with
$10 \%$ fetal bovine serum, penicillin/streptomycin (250 $\mathrm{U} / \mathrm{mL})$, gentamycin $(100 \mu \mathrm{g} / \mathrm{mL})$ and amphotericin B $(1 \mathrm{mg} / \mathrm{mL})$. All cell cultures were maintained at $37^{\circ} \mathrm{C}$ in a humidified atmosphere of $5 \% \mathrm{CO}_{2}$. Cells were allowed to grow to confluence over $24 \mathrm{~h}$ before use.

\section{Cytotoxicity assay}

Cytotoxicity was determined using MTT [3-(4,5dimethylthiazol-2-yl)-2,5-diphenyltetrazolium bromide] assay (Mosmann, 1983). Cells $\left(1 \times 10^{5} /\right.$ well $)$ were plated in 24-well plates and incubated in $37^{\circ} \mathrm{C}$ with $5 \% \mathrm{CO}_{2}$ condition. After the cell reaches the confluence, the various concentrations $(15.6,31.2,62.5,125,250,500$ and $1000 \mu \mathrm{g} / \mathrm{ml}$ ) of the ethyl acetate extract of $P$. cyaneum were added and incubated for $24 \mathrm{hrs}$. After incubation, the sample was removed from the well and washed with phosphate-buffered saline ( $\mathrm{pH}$ 7.4) or MEM without serum. $100 \mu \mathrm{l} / \mathrm{well}(5 \mathrm{mg} / \mathrm{ml})$ of $0.5 \% 3-(4,5-$ dimethyl-2-thiazolyl)-2,5-diphenyl--tetrazolium bromide (MTT) was added and incubated for 4 hours. After incubation, $1 \mathrm{ml}$ of DMSO was added in all the wells. The absorbance at $570 \mathrm{~nm}$ was measured with UVSpectrophotometer using DMSO as the blank. Measurements were performed and the concentration required for a 50\% inhibition (IC50) was determined graphically. The morphological changes of the HepG 2 cells were microscopically observed.

The $\%$ cell viability was calculated using the following formula:

$\%$ cell viability $=\mathrm{A}_{570}$ of treated cells $/ \mathrm{A}_{570}$ of control cells $\times 100$

Graphs are plotted using the \% of Cell Viability at Yaxis and concentration of the sample in $\mathrm{X}$-axis. Cell control and sample control is included in each assay to compare the full cell viability assessments.

\section{Results and Discussion}

In the present study, $P$. cyaneum was isolated and identified from mangrove soils of Karankadu, Ramanathapuram Dt. Macro and micro morphology of isolated P. cyaneum was shown in Figure 1.

\section{Scientific Classification of $P$. cyaneum}

$\begin{array}{lll}\text { Class } & : & \text { Eurotiomycetes } \\ \text { Order } & : & \text { Eurotiales } \\ \text { Family } & : & \text { Trichocomaceae }\end{array}$


Genus : : Penicillium

Species : cyaneum

Synonymous : $\quad$ Citromyces cyaneus

\section{Macroscopic Observation of $P$. cyaneum}

Colony morphology on PDA medium growing restrictedly, consisting of a close-textured basal felt, radically furrowed, with central areas commonly raised, surface appearing velvety, gray-green, re-verse colorless.

\section{Microscopic Observation of $P$. cyaneum}

Conidiophores arising branches from ascending aerial hyphae, with walls smooth, irregularly branched, penicilli monoverticillate, small, usually consisting of closely crowded verticils of 5 to 8 parallel sterigmata, conidia elliptical, with ends often more or less pointed, smooth-walled.

\section{Cytotoxicity of $P$. cyaneum against HepG2 cell lines}

The results of cytotoxicity of $P$. cyaneum against HepG2 cell lines were illustrated in Table 1 and Figure 1. The ethyl acetate extract of $P$. cyaneum showed significant cytotoxicity in the HepG 2 cells (human liver carcinoma cells). The results are in harmony with the findings of Joel and Bhimba (2012). They reported the considerable cytotoxic effect of the crude extracts of Pestalotiopsis microspora VB5 at various concentrations against Hep 2 cell lines. Recently a study by Suja et al., (2014) who accounted Aspergillus terreus showed better activity against HepG2 cell line. Bioactive compounds such as sargassamide, halimide and avrainvillamide isolated from a marine fungus have shown selective inhibition against cancer cell lines, and shown in vivo activity in preclinical models (P-388 lymphocytic leukemia) (Bhadury et al., 2006).

Table.1 Cytotoxicity of $P$. cyaneum against HepG2 cell lines

\begin{tabular}{|c|c|c|c|c|}
\hline S. No. & Concentration $(\mu \mathrm{g} / \mathrm{ml})$ & Dilutions & $\begin{array}{c}\text { Absorbance } \\
(\text { O.D) }\end{array}$ & Cell Viability (\%) \\
\hline 1 & 1000 & Neat & 0.09 & 29.5 \\
\hline 2 & 500 & $1: 1$ & 0.13 & 38.2 \\
\hline 3 & 250 & $1: 2$ & 0.17 & 51.6 \\
\hline 4 & 125 & $1: 4$ & 0.21 & 59.5 \\
\hline 5 & 62.5 & $1: 8$ & 0.29 & 63.5 \\
\hline 6 & 31.2 & $1: 16$ & 0.35 & 71.0 \\
\hline 7 & 15.6 & $1: 32$ & 0.41 & 85.1 \\
\hline 8 & Cell control & - & 0.59 & 100 \\
\hline
\end{tabular}

Fig.1 Macro and Macroscopic view of P. cyaneum
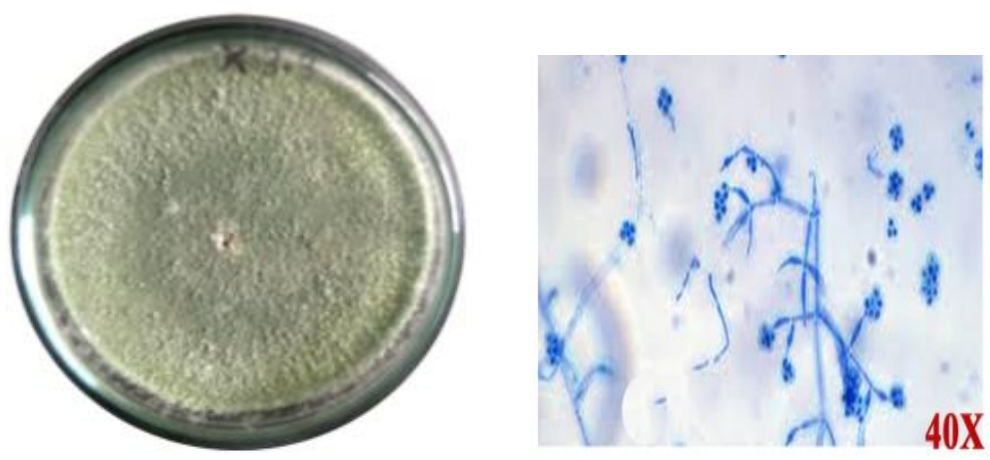
Fig.2 Cytotoxicity of P. cyaneum against HepG2 cell lines

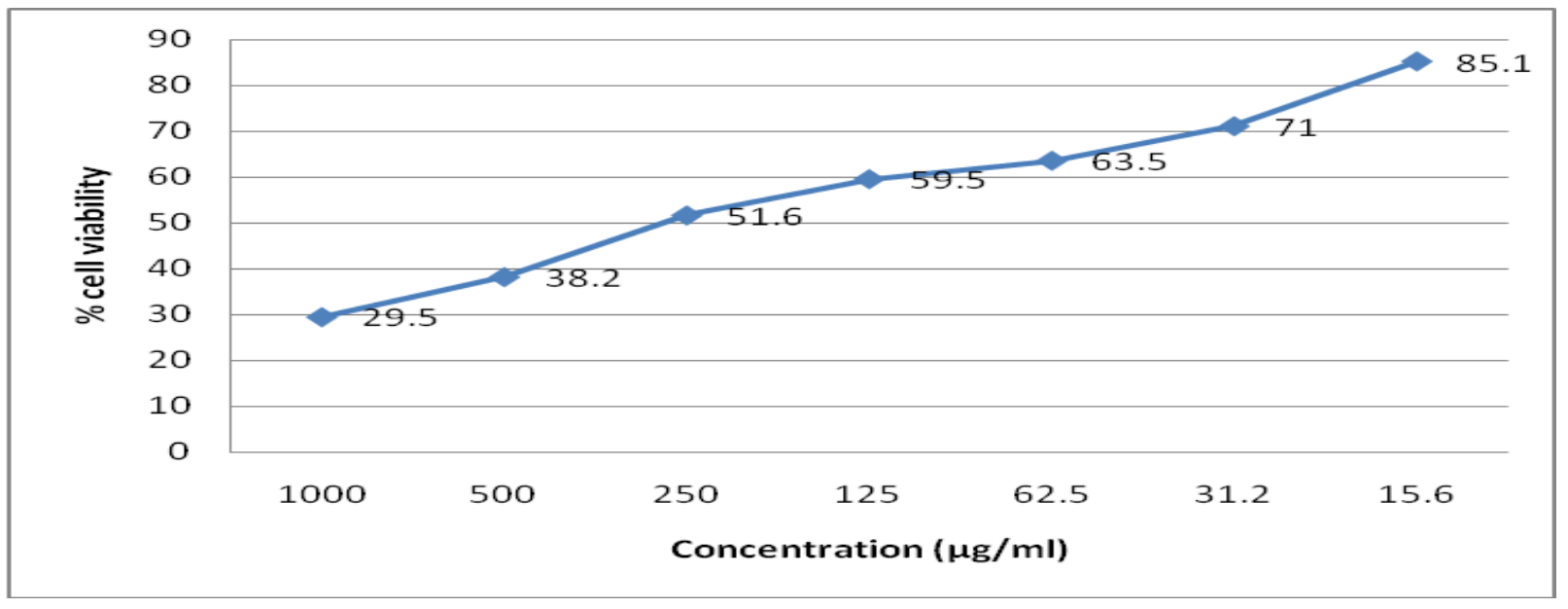

Fig.3 Morphology of HepG2 cells treated with ethyl acetate extract of $P$. cyaneum

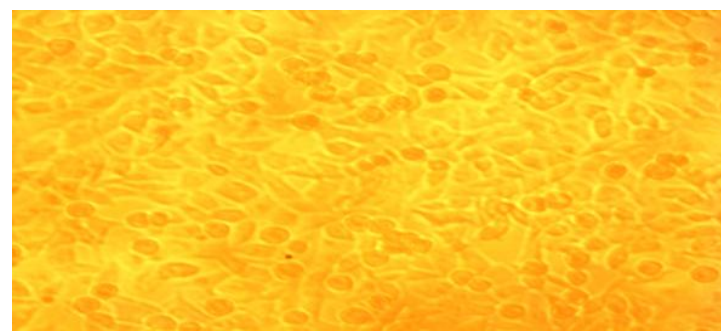

Normal HEP G 2Cell line

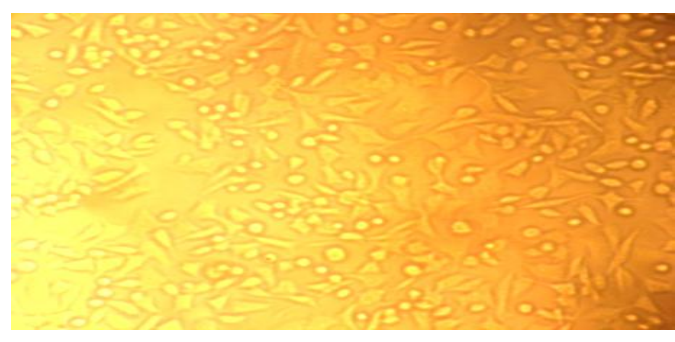

Toxicity $-62.5 \mu \mathrm{g} / \mathrm{ml}$

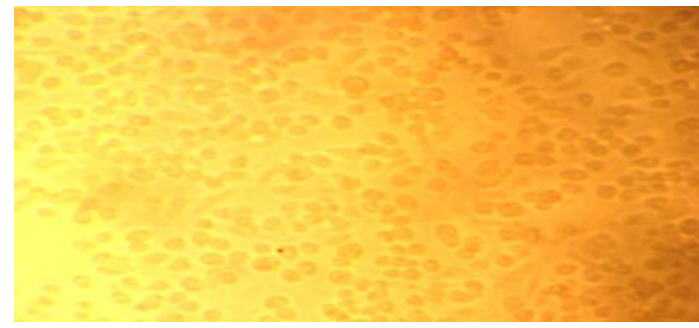

Toxicity $-250 \mu \mathrm{g} / \mathrm{ml}$

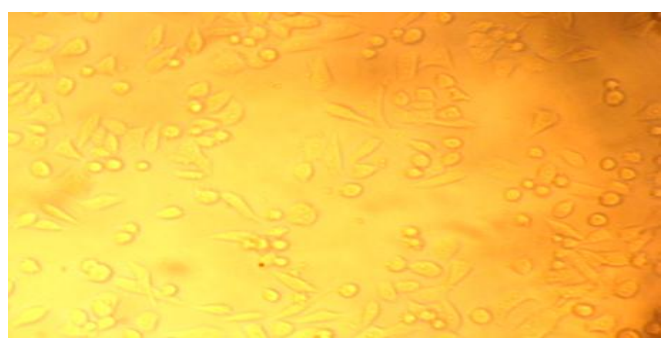

Toxicity $-125 \mu \mathrm{g} / \mathrm{ml}$

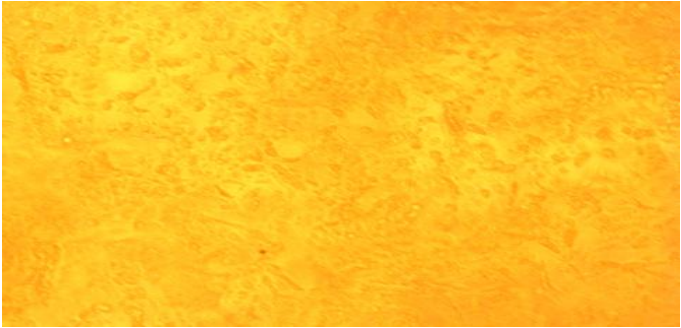

Toxicity $-1000 \mu \mathrm{g} / \mathrm{ml}$ 
In the present investigation, $P$. cyaneum ethyl acetate extract showed potent cytotoxic effects in HepG 2 cells, with cell viability $(29.5 \%)$ observed at $1000 \mu \mathrm{g} / \mathrm{mL}$. The $\mathrm{IC}_{50}$ of ethyl acetate extract of $P$. cyaneum was 242.24 $\mu \mathrm{g} / \mathrm{mL}$. Similar findings have been reported for marinederived fungi Neosartorya paulistensis and Neosartorya siamensis showed decrease the number of viable cells, with an IC50 lower than $200 \mathrm{mg} / \mathrm{mL}$ in HCT116, A375 and HepG2 cells by Ramos et al., (2015).

In the same way, anticancer activity of various marine fungi such as Clonostachys sp. ESNA-A009 against LNcaP (prostate cancer), SK-BR3 (breast cancer), HT29 (colon cancer), and HELA (cervix cancer) (Cruz et al., 2006), Acremonium sp. against HCT-116 cells (Boot et al., 2007), Eurotium cristatum against MCF-7 (breast adenocarcinoma), NCI-H460 (lung cancer), and A375C5 (melanoma) (Almeida et al., 2010), Xylaria psidii against bladder carcinoma cell line 5637 (ATCC HTB9) (Tarman et al., 2011), Neosartorya siamensis against HepG2, HCT116 and A375 cancer cell lines (Prata-Sena et al., 2014) and Penicillium oxalicum against BGC823 gastric cancer and MOLT4 acute lymphoblastic leukemia cell lines (Bao et al., 2014) have been reported.

The cytotoxicity effect of ethyl acetate extract of $P$. cyaneum was also confirmed by a decrease of cell density and also by structural alterations, such as rounded and detached cells as observed in a phase contrast microscope (Figure 3). Similarly Suja et al., (2014) reported the morphological characteristics of the HpG2 cells treated with active fractions of Aspergillus terreus such as rounding of cells, shrinkage, aggregation, cell death etc., and it was observed through phase contrast microscope. To the best of our knowledge this is the first report on the in vitro anticancer activity of mangrove derived fungi $P$. cyaneum.

\section{Conclusion}

The present study shows that the mangrove isolate $P$. cyaneum can be a good source for alternative therapy of cancer cells, however further investigations are required to determine the anticancer compounds in the marine fungus.

\section{References}

Almeida, A.P., Dethoup, T., Singburaudom, N., Lima, R., Vasconcelos, M.H., Pinto, M. and Kijjoa, A. 2010. The in vitro anticancer activity of the crude extract of the sponge-associated fungus Eurotium cristatum and its secondary metabolites. J. Nat. Pharm., 1(1): 25-29.

Bao, J., Luo, J.F., Qin, X.C., Xu, X.Y., Zhang, X.Y., Tu, Z.C. and Qi, S.H. 2014. Dihydrothiophene condensed chromones from a marine-derived fungus Penicillium oxalicum and their structure- bioactivity relationship. Bioorg. Med. Chem. Lett., 24(11): 2433-2436.

Bhadury, P., Mohammad, B.T. and Wright, P.C. 2006. The current status of natural products from marine fungi and their potential as anti-infective agents. $J$. Ind. Microbiol. Biotechnol., 33: 325-337.

Boot, C.M., Amagata, T., Tenney, K., Compton, J.E., Pietraszkiewicz, H., Valeriote, F.A., and Crews, P. 2007. Four classes of structurally unusual peptides from two marine-derived fungi: structures and bioactivities. Tetrahedron, 63(39): 9903-9914.

Cruz, L.J., Insua, M.M., Baz, J.P., Trujillo, M., Rodriguez-Mias, R.A., Oliveira, E., Giralt, E., Albericio, F. and Canedo, L.M. 2006. IB-01212, a new cytotoxic cyclodepsipeptide isolated from the marine fungus Clonostachys sp. ESNA-A009. J. Org. Chem., 71(9): 3335-3338.

Dikshit, R., Gupta, P.C. and Ramasundarahettige, C. 2012. Cancer mortality in India: a nationally representative survey. Lancet, 379(9828): 18071816.

Gillman, J.C. 1957. A Manual of Soil Fungi. Revised 2nd edition Oxford and IBH publishing company (Indian reprint) Calcutta, Bombay, New Delhi.

Gomes N.G.M., Lefranc, F., Kijjoa, A. and Kiss, R. 2015. Can Some Marine-Derived Fungal Metabolites Become Actual Anticancer Agents? Mar. Drugs, 13: 3950-3991.

Joel, E.L. and Bhimba, B.V. 2012. Fungi from Mangrove plant: their antimicrobial and anticancer potentials. Int. J. Pharma. Pharmaceut. Sci., 4: 139-142.

Mosmann, T. 1983. Rapid colorimetric assay for cellular growth and survival: Application to proliferation and cytotoxicity assays. J. Immunol. Methods, 65: 55-63.

Nandakumar, A. 2009. National Cancer Registry Programme, Indian Council for Medical Research, Consolidated report of the population based cancer registries 1990-96, Indian Council of Medical Research, New Delhi.

Prata-Sena, M., Ramos, A., Castro-Carvalho, B., Dethoup, T., Buttachon, S., Kijjoa, A., \& Rocha, E. 2014. Anti-proliferative and pro-apoptotic activities of two marine sponge-derived fungi extracts in HepG2, HCT116 and A375 cancer cell lines. Planta Medica, 80(16): P1N3. 
Raper, K.B. and Thom, C. 1949. A Manual of Penicillia. Williams and Wilkins Co., Baltimore, Md., U.S.A.

Rateb, M.E. and Ebel, R. Secondary metabolites of fungi from marine habitats. Nat. Prod. Rep., 28: 290-344.

Suja, M., Vasuki, S. and Sajitha, N. 2014. Anticancer activity of compounds isolated from marine endophytic fungus Aspergillus terreus. World J. Pharm. Pharm. Sci., 3(6): 661-72.

Tarman, K., Lindequist, U., Wende, K., Porzel, A., Arnold, N. and Wessjohann, L.A. 2011. Isolation of a new natural product and cytotoxic and antimicrobial activities of extracts from fungi of Indonesian marine habitats. Mar. Drugs, 9: 294306.

Waksman, S.A. 1922. A method for counting the number of fungi in the soil. J. Bact., 7(3): 339-341.

WHO. 2017. World Health Organization, Cancer, Fact sheet, http://www.who.int/ mediacentre/ factsheets/fs297/en/

\section{How to cite this article:}

Xavier Fernandes, A., S. Mohamed Salique and Umamagheswari, K. 2017. In Vitro Anticancer Activity of Marine Fungus Penicillium cyaneum. Int.J.Curr.Res.Aca.Rev. 5(4), 76-81.

doi: https://doi.org/10.20546/ijcrar.2017.504.011 